\title{
Temporal variation of epi- and endofaunal assemblages associated with the red sponge Tedania ignis on a rocky shore (São Sebastião Channel), SE Brazil
}

\author{
Fosca P. P. Leite', Lilian Pavani' \& Marcel O. Tanaka²
}

\author{
1. Departamento de Biologia Animal, Universidade Estadual de Campinas, Caixa Postal 6109, 13083-970 Campinas, SP, Brazil. \\ (fosca@unicamp.br; lilianpavani@yahoo.com.br) \\ 2. Departamento de Ciências Ambientais (DCAm), Universidade Federal de São Carlos, Caixa Postal 676, 13565-905, São Carlos, SP, Brazil. \\ (martnk@yahoo.com)
}

Received 11 June 2015

Accepted 28 April 2016

DOI: $10.1590 / 1678-4766 e 2016007$

\begin{abstract}
Sponges are biogenic substrates that increase the available space on rocky shores and provide shelter for many groups of the benthic fauna, which can live both inside and on these sessile invertebrates. In order to assess the differences in temporal variation of endobiont and epibiont groups, samples of the red sponge Tedania ignis (Duchassaing \& Michelotti, 1864) were obtained each month for one year. The density, richness and diversity of endobiont and epibiont groups were analyzed in relation to abiotic factors. The dry mass of the sponge was negatively correlated with the density of individuals in both groups and positively with the diversity of endobionts, while organic matter was positively correlated with the diversity of epibionts. Endobiont diversity was more highly correlated with intrinsic factors of the sponge, whereas the diversity of epibionts was more highly correlated with factors related to the surrounding environment.
\end{abstract}

KEYWORDS. Biogenic substrate, associated fauna, diversity indicators, temporal variation.

RESUMO. Variação temporal das assembleias de epi- e endofauna associadas com a esponja vermelha Tedania ignis em um costão rochoso (Canal de São Sebastião), SE, Brasil. As esponjas são substratos biogênicos que aumentam o espaço tridimensional disponível nos costões e proporcionam abrigo para uma grande numero de táxons da fauna bentônica, que podem viver tanto dentro como sobre esses invertebrados sésseis. Buscando avaliar as diferenças na variação temporal de táxons endobiontes e epibiontes, foram obtidas amostras mensais da esponja Tedania ignis (Duchassaing \& Michelotti, 1864) durante um ano. Foram analisadas a densidade, riqueza e diversidade dos táxons endobiontes e epibiontes que foram relacionadas com a influência dos fatores abióticos. Observou-se que a massa seca da esponja influenciou negativamente a densidade de indivíduos nos dois grupos e apresentou resultado positivo sobre a diversidade de endobiontes, enquanto que a matéria orgânica foi o fator que influenciou positivamente a diversidade de epibiontes. Foi avaliado que a diversidade de endobiontes depende mais de fatores intrínsecos da esponja enquanto que a diversidade de epibiontes está mais relacionada com os fatores condicionados pelo meio ao redor.

PALAVRAS-CHAVE. Substrato biológico, fauna associada, indicadores de diversidade, variação temporal.

Biogenic substrates contribute significantly to marine biodiversity, especially on rocky shores, since they increase the range of spatial and food resources available to the benthic fauna (SEBENS, 1991). The organisms that form these substrates are considered ecosystem engineers, increasing local habitat complexity and therefore influencing biodiversity patterns (Voultsiadou et al., 2007). Biogenic substrates such as sponges (DuARTE \& NALESSO, 1996; Ribeiro et al., 2003; MARIN, 2007; GARCIA et al., 2009), sabellariid polychaetes (NAlesso et al., 1995; Bosa \& MASUnARI, 2002a,b), bryozoans (CONRADi et al., 2000; MoRgado \& TANAKA, 2001), mussels (JACOBI, 1987; O’CONNOR \& CROWE, 2007), barnacles (CRAIN \& BERTNESS, 2006), ascidians (CASTILlA et al., 2004) and macroalgae (TARARAM \& WAKABARA, 1981;
Masunari, 1982; JaCOBUCCI \& LeITe, 2002; TANAKa \& LEITE, 2003) shelter a rich and diverse fauna in varied types of association, including commensalism, mutualism and parasitism.

Sponges are used as shelter and food resources by a diverse and abundant fauna (DUARTE \& NALESSO, 1996; RiBeIRo et al., 2003; MARIN, 2007; GARCIA et al., 2009). The associated fauna is mainly composed of amphipods, polychaetes, decapods, and molluscans, both on sponge surfaces (epibionts) and within the canal systems (endobionts) (Voultsiadou-Koukouras, 1987; Duarte \& Nalesso, 1996; RIBEIRO et al., 2003). Variations in sponge architecture such as size, texture, and morphology (KLITGAARD, 1995; Koukouras et al., 1996), as well as space availability 
within the sponges (KouKouras et al., 1985; VILLAMIZAR \& Laughlin, 1991; Klitgaard, 1995; Neves \& Omena, 2003; АBDO, 2007), determine differences in microhabitat complexity, influencing the distribution of the associated fauna. The presence of secondary metabolites produced by the sponges to deter predators can also influence the structure of the associated assemblage (SKILLETER et al., 2005), by preventing organisms from attaching to the sponge surfaces (RIBEIRO et al., 2003). Further, local environmental conditions such as depth and water quality modulate biological effects on the composition and diversity patterns of the associated assemblages (Peattie \& HoARe, 1981; Westinga \& HoetJes, 1981; RIBEIRO et al., 2003).

Since secondary biogenic substrata contribute to ameliorate local environmental conditions such as temperature, desiccation, salinity and hydrodynamics (PAWLIK et al., 2007), it is expected that epifaunal assemblages are more subject to variation in these conditions than endofaunal assemblages are. These assemblages would be more related to the availability of internal space of the biogenic substrata (Morgado \& Tanaka, 2001), due to shelter and food accumulation (VILlamizar \& LAUGHLin, 1991). Thus, higher temporal variation of epifaunal assemblages would be found in epifaunal than in endofaunal assemblages, but this prediction has not yet been directly tested. Here, we evaluated temporal variation of assemblages associated with the sponge Tedania ignis (Duchassaing \& Michelotti, 1864), which occurs conspicuously on rocky substrates in tropical Atlantic regions such as in the midlittoral of the Brazilian coast (MurICY \& HAJdu, 2006; CusTóDIO \& HAJDU, 2011). We expected that temporal variation of the epifaunal assemblages would be more related to abiotic factors than would variation of the endofaunal assemblages.

\section{MATERIAL AND METHODS}

Sampling was carried out monthly from August 2004 through July 2005 during diurnal spring tides on the northern

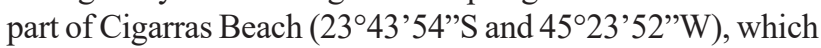
is located in the São Sebastião district, northern coast of São Paulo State, SE Brazil. In each sampling, a $50 \mathrm{~m}$-long area was marked and six samples of Tedania ignis were randomly collected from the lower intertidal with a putty knife. Each sample was placed in a cloth bag with $0.2 \mathrm{~mm}$ mesh.

The samples were collected after careful observation of the external anatomy and color of Tedania ignis to ensure species identification, since it was noted the presence of other sponge species in the area. All samples were placed in plastic bags and stored in a cooler with ice for preservation, to prevent the output of the aquifer endofauna from the canal system and transported to the laboratory. During each sampling time, we measured seawater temperature with a mercury thermometer, and determined water salinities from three seawater samples with an optical refractometer. Sediment from the same area were sampled with a putty knife, stored in plastic bags, transported in a cooler with ice, and later frozen. In the laboratory, the organic matter content $(\mathrm{OM})$ in the sediment was determined in percentage, following Amoureux (1966).

In the laboratory, the volume of each sponge sample was determined with the water displacement method, using a graduated cylinder filled with seawater. After measuring, all samples were frozen to maintain their original characteristics and facilitate faunal extraction. The sponges were examined under a stereomicroscope to separate the epifaunal individuals on the sponge surface; then, the sponge was carefully fragmented to extract the endofaunal individuals from the canal system. All organisms found were preserved in $70 \%$ ethanol, and later identified to major taxonomic groups. After faunal extraction, the sponge fragments were oven-dried at $70^{\circ} \mathrm{C}$ for 48 hours, and their dry mass (DM) determined with a digital balance $($ precision $=0.001)$.

The specimens of the taxa studied, including sponge samples, are deposited in the Coleção de Invertebrados of LICOMAR (Laboratório de Interações em Comunidades Marinhas), DBA, IB, UNICAMP. Tedania ignis was identified after observation of tissue fragments slides with the presence of specific spicules (MURICY \& HAJDU, 2006).

Data analysis. The number of individuals in each replicate was standardized to $100 \mathrm{ml}$ of sponge. To evaluate whether environmental factors or sponge characteristics were more important in structuring the epi- and endofaunal assemblages, we used stepwise multiple regression. Dependent variables evaluated were total density, taxon richness, and Shannon-Wiener diversity index. The independent variables were temperature, OM, and DM. The other variables measured were not used, to avoid multicollinearity problems, because they were highly correlated to independent variables according to Pearson's correlation coefficient (sponge volume x sponge dry mass: $r=0.89, P<0.001$; temperature $\mathrm{x}$ salinity: $r=-0.827, P<0.001)$.

To evaluate temporal variation in the epi- and endofaunal assemblages, we carried out a Multidimensional Scaling (MDS) analysis on the similarity matrix calculated using the Bray-Curtis index (Clarke, 1993). Densities were previously transformed to logarithms to balance the contributions of rare and dominant taxa (CLARKE, 1993). Differences between epi- and endofaunal assemblages were evaluated with one-way Analysis of Similarities (ANOSIM), and the taxa that most contributed to these differences were identified using the Similarity Percentage Breakdown method, using the software Primer 6.0 (Clarke, 1993).

\section{RESULTS}

A total of 5,234 individuals in 63 sponge samples were obtained. Epibionts were far more abundant (4,186 individuals) then endobionts (1,048 individuals). The assemblages were constituted mainly of the mobile taxa Nematoda, Turbellaria, Bivalvia, Gastropoda, Polychaeta, Ostracoda, Copepoda, Decapoda, Tanaidacea, Isopoda, Amphipoda, Pycnogonida, Acarina, Sipuncula, and Ophiuroidea, and the sessile taxa Porifera, Hydrozoa, Cirripedia, Bryozoa and Ascidiacea. Nematoda, Bivalvia, Amphipoda, and Polychaeta comprised 
$76 \%$ of all organisms. Epifaunal assemblages were dominated by Bivalvia, Nematoda, Amphipoda and Polychaeta, which together comprised $74 \%$ of the epifauna. On the other hand, endofaunal assemblages were dominated by Nematoda, Bivalvia and Polychaeta, comprising $81 \%$ of the endofauna.

There was wide variation in sponge sizes (dry mass DM) during the study period, with higher values between August and November (Fig. 1). Diversity indicators also varied during the period (Fig. 1). However, temperature did not influence the diversity indicators, only the organicmatter content (OM) and sponge dry mass (DM) (Tab. I). For epifaunal assemblages (Fig. 2), total densities were related negatively to $\mathrm{DM}$ and positively to $\mathrm{OM}\left(\mathrm{R}^{2}=0.82\right)$, the Shannon-Wiener diversity was positively related to $\mathrm{OM}$ $\left(\mathrm{R}^{2}=0.39\right)$, and taxon richness was positively related to $\mathrm{OM}$, although with a marginal value $\left(\mathrm{R}^{2}=0.34, P=0.058\right.$; Tab. I). For the endofaunal assemblages, diversity indicators were strongly related to dry mass (DM) (Fig. 2, Tab. I), with the exception of taxon richness, which was also positively related to $\mathrm{MO}$, although with a marginal value $(P=0.085)$.

Epifaunal taxa showed higher temporal variation than endofaunal ones, with higher abundances of epifauna
(Fig. 3). Most groups increased in density during the winter, with higher differentiation between epi- and endofaunal assemblages during this period. Among the dominant groups, Bivalvia, Polychaeta and Amphipoda tended to show higher values in the epifauna throughout the year, whereas Nematoda showed higher endofaunal numbers during only two months of the period (Fig. 3).

The mean similarity of the endofaunal assemblages among months was $53.6 \%$, a value much higher than the mean similarity of the epifaunal assemblages, which was $42.4 \%$. On the other hand, the mean dissimilarity between assemblage types was high $(70.8 \%)$, due to the higher abundances of all taxa in epifaunal than in endofaunal assemblages (SIMPER), especially during the colder months (Fig. 4). Thus, highly significant differences were found between assemblages (ANOSIM, $R=0.551, P<0.001$ ).

\section{DISCUSSION}

The assemblages associated with Tedania ignis showed wide temporal variation. As expected, the epifaunal assemblages showed wider variation in faunal composition
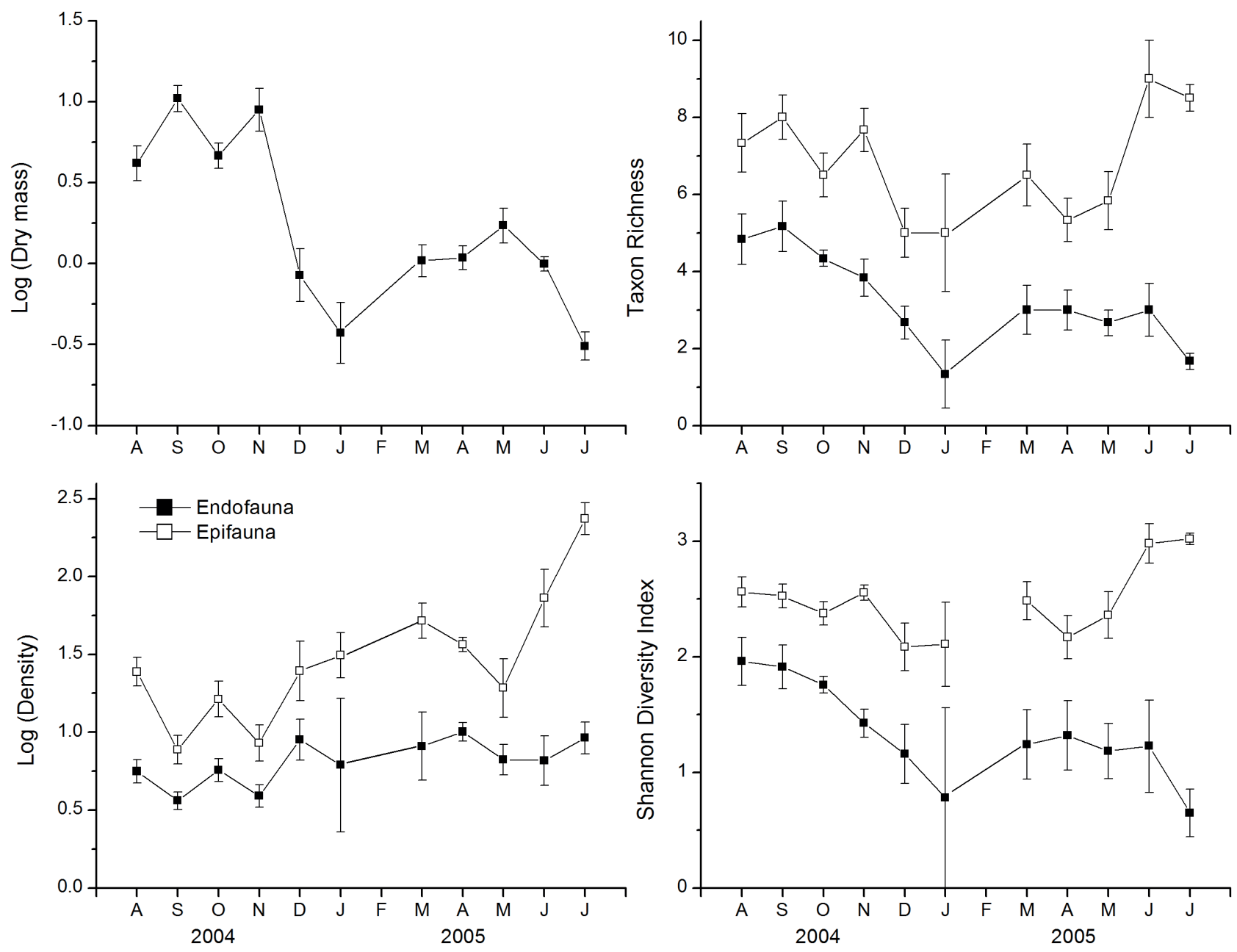

Fig. 1. Temporal variation of sponge biomass, and density, taxon richness and Shannon diversity index of epifaunal (open symbols) and endofaunal (closed symbols) assemblages associated with Tedania ignis at Praia das Cigarras, São Sebastião, São Paulo, Brazil. Values are means \pm SE. 
than the endofaunal assemblages. The epifaunal diversity indicators were more correlated to environmental factors than the endofaunal diversity indicators, which basically responded to sponge biomass, an indicator of available space for colonization. Finally, both epi- and endofaunal densities were correlated to sponge biomass, although higher densities were found on the sponge surface than in its interior. In a recent review, CHRISTIE et al. (2009) found that faunal
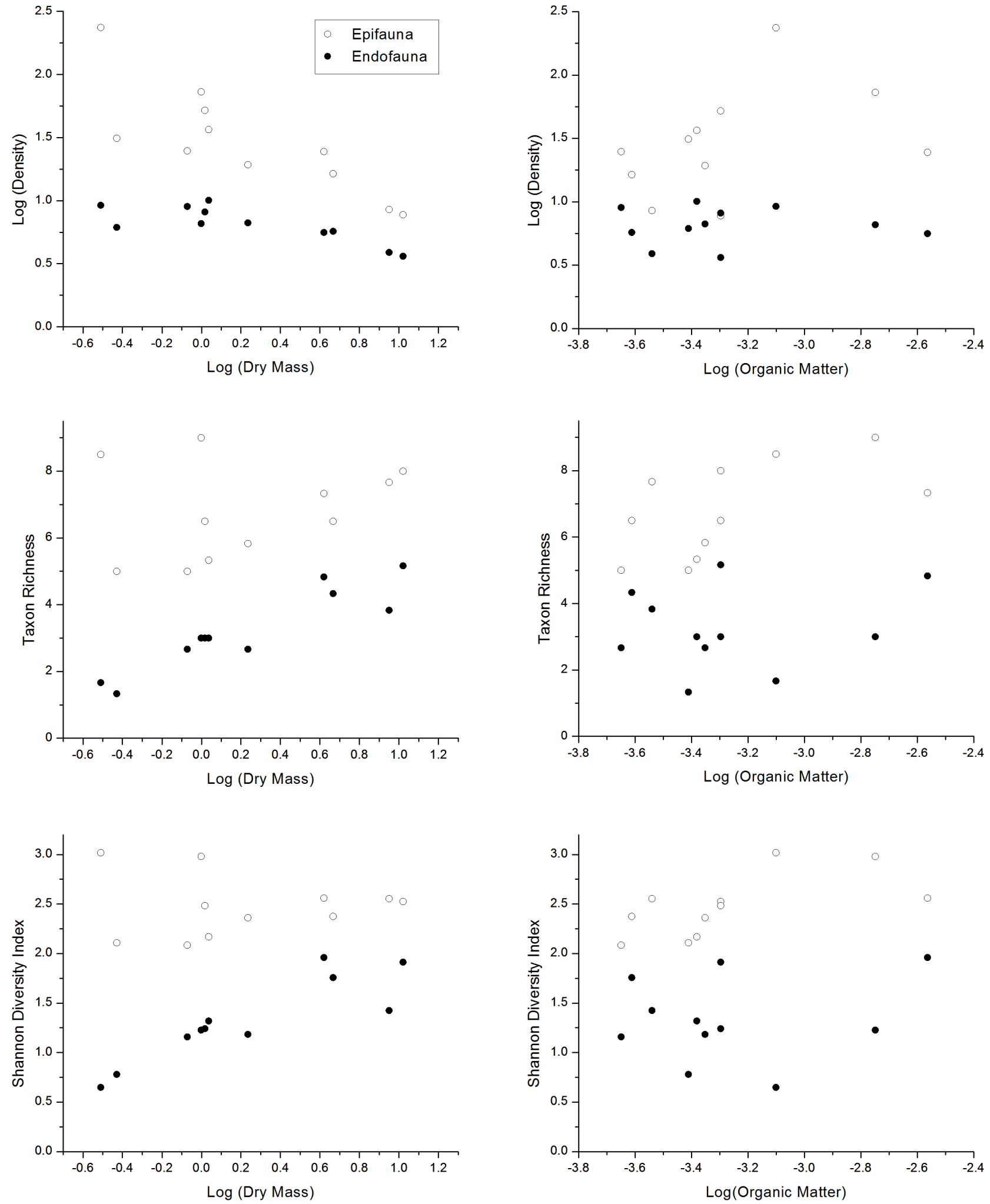

Fig. 2. Variation of density, taxon richness and Shannon diversity index of epifaunal (open symbols) and endofaunal (closed symbols) assemblages associated with Tedania ignis in relation to sponge biomass and organic matter content at Praia das Cigarras, São Sebastião, São Paulo, Brazil. 

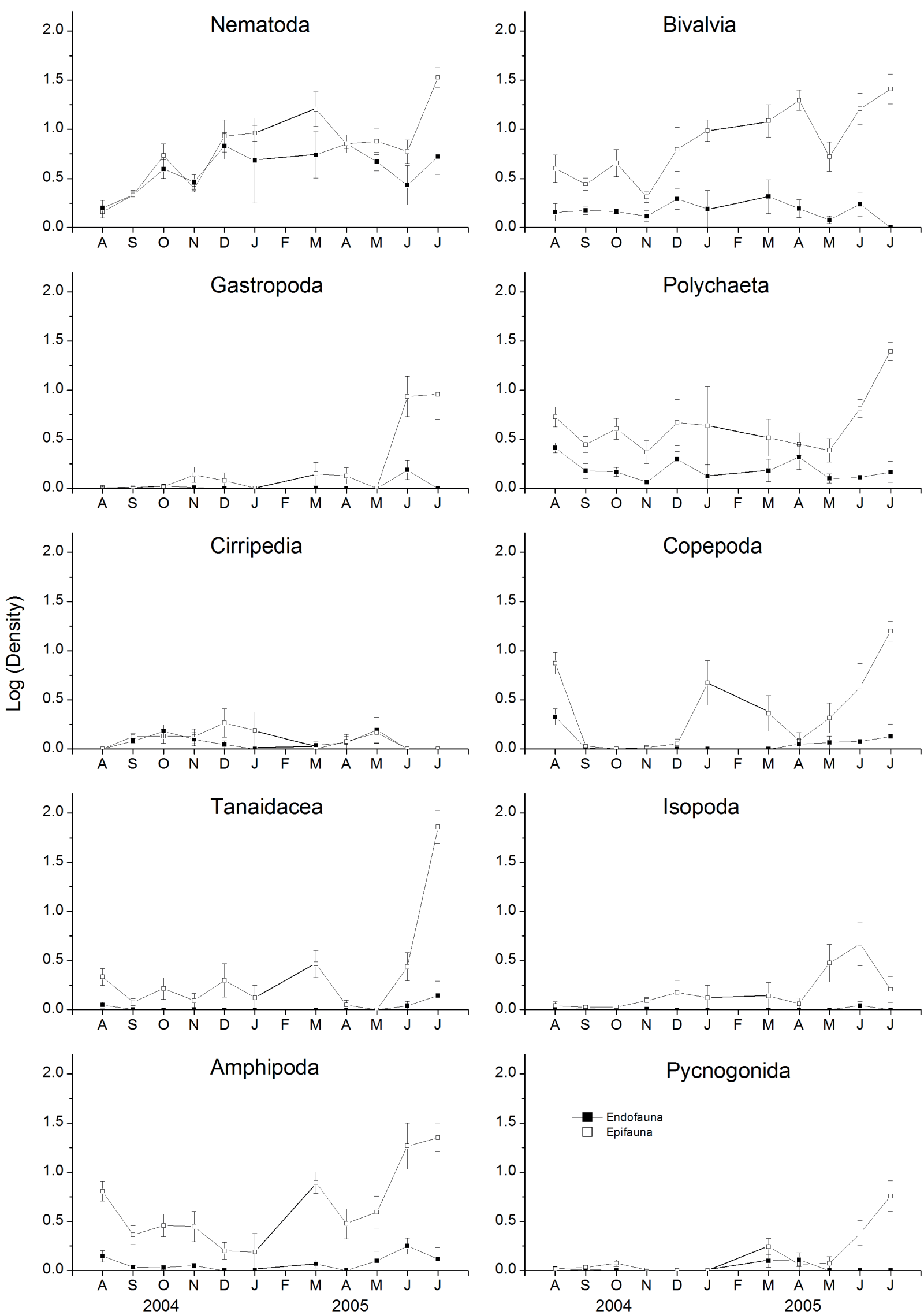

Fig. 3. Temporal variation of the main taxonomic groups of epifaunal (open symbols) and endofaunal (closed symbols) assemblages associated with Tedania ignis at Praia das Cigarras, São Sebastião, São Paulo, Brazil. Values are means \pm SE. 
Tab. I. Results of stepwise multiple regression to assess the influence of sponge dry mass, temperature and organic matter on the total density and diversity indicators (taxon richness and Shannon-Wiener diversity index) of epifaunal and endofaunal assemblages associated with Tedania ignis at Praia das Cigarras, São Sebastião, São Paulo, Brazil.

\begin{tabular}{|c|c|c|c|c|}
\hline Dependent variable & Selected Model & Coeficient & EP & $\mathrm{P}$ \\
\hline \multicolumn{5}{|l|}{ Epifauna } \\
\hline Shannon-Wiener diversity index & Constant & 4.34 & 0.775 & $<0.001$ \\
\hline $\mathrm{R}^{2}=0.39, \mathrm{P}=0.039$ & Organic Matter & 0.57 & 0.236 & 0.039 \\
\hline Taxon richness & Constant & 14.69 & 3.659 & 0.003 \\
\hline $\mathrm{R}^{2}=0.34, \mathrm{P}=0.058$ & Organic Matter & 2.42 & 1.114 & 0.058 \\
\hline Total density & Constant & 3.03 & 0.625 & 0.001 \\
\hline \multirow[t]{2}{*}{$\mathrm{R}^{2}=0.81, \mathrm{P}=0.001$} & Sponge dry mass & -0.66 & 0.126 & 0.001 \\
\hline & Organic Matter & 0.43 & 0.191 & 0.053 \\
\hline \multicolumn{5}{|l|}{ Endofauna } \\
\hline Shannon-Wiener diversity index & Constant & 1.16 & 0.069 & $<0.001$ \\
\hline $\mathrm{R}^{2}=0.78, \mathrm{P}<0.001$ & Sponge dry mass & 0.71 & 0.127 & $<0.001$ \\
\hline Taxon richness & Constant & 5.33 & 1.331 & 0.004 \\
\hline \multirow[t]{2}{*}{$\mathrm{R}^{2}=0.90, \mathrm{P}<0.001$} & Sponge dry mass & 2.18 & 0.268 & $<0.001$ \\
\hline & Organic Matter & 0.80 & 0.406 & 0.085 \\
\hline Total density & Constant & 0.86 & 0.030 & $<0.001$ \\
\hline $\mathrm{R}^{2}=0.65, \mathrm{P}=0.003$ & Sponge dry mass & -0.23 & 0.055 & 0.003 \\
\hline
\end{tabular}

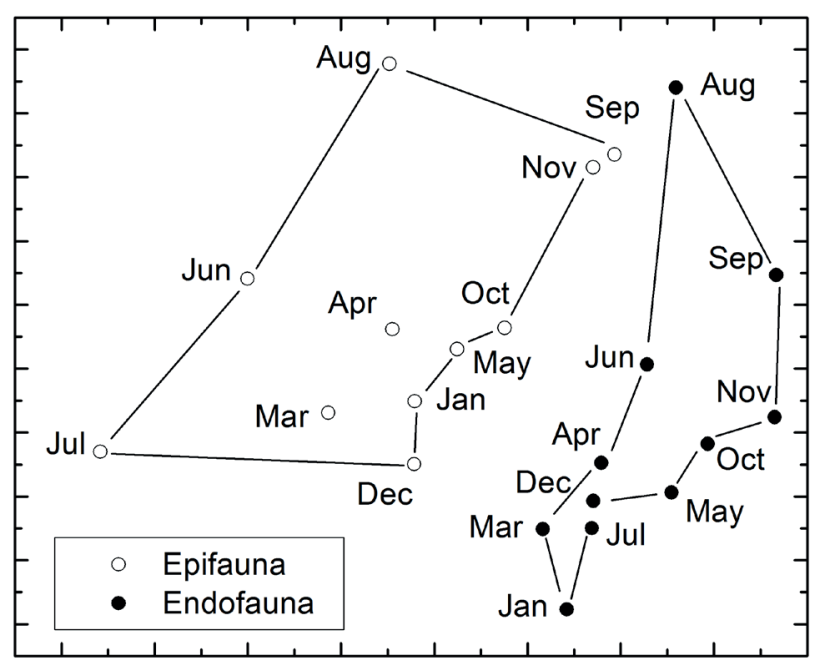

MDS - Axis 1

Fig. 4. MDS ordination of epifaunal (open symbols) and endofaunal (closed symbols) assemblages associated with Tedania ignis at Praia das Cigarras, São Sebastião, São Paulo, Brazil during one year. Stress $=0.06$.

abundances on macrophytes depend on habitat size but not on habitat complexity, as also found here. In fact, both epi- and endofaunal densities were strongly correlated with sponge biomass.

In São Sebastião, the faunal groups found associated with Tedania ignis are also commonly found associated with macroalgae (NASCIMENTO \& Rosso, 2007), as also observed for the fauna associated with sponges elsewhere (PEATTIE \& Hoare ,1981; KlitgaArd, 1995; Voultsiadou et al., 2007; HuANG et al., 2008; Fiore \& JutTE, 2010). Epifaunal activities may clean sponge surfaces from debris, by feeding and building tubes, while the sponge provides a perennial and physically stable structure for the fauna (COSTELLO \& MYERS, 1987). Endofaunal abundances within sponges can be lower than epifaunal abundances on sponge surfaces and on other biological surfaces, so that fewer organisms may have adequate traits to inhabit the interior of these animals (FIORE \& JutTE, 2010). There is a strong relationship between sponge internal space (channel sizes) and the densities and sizes of endofaunal organisms (ABDO, 2007). FIORE \& JUTTE (2010) found that channel diameter could negatively influence endofaunal densities, and therefore, endofaunal diversity. There are no studies on internal space availability and channel diameters of $T$. ignis, but we could note visually that the channels are narrow. Therefore, the small spaces available limited their use by a numerous and diverse fauna, and they were used primarily by few, small-sized taxa.

Although internal space was not measured, endofaunal diversity indicators were strongly correlated with sponge biomass, indicating that this resource can be limiting for these communities. This relationship is commonly found in associations between sponges and their associated macrofauna (Koukouras et al., 1985; Ribeiro et al., 2003; PAdua et al., 2013; Ávila \& OrTega-Bastida, 2014), and this pattern can be related to limited spatial resources on primary substrates, mainly for endofaunal assemblages. These studies found a positive relationship between macrofaunal diversity and sponge biomass or volume when comparing these effects within sponge species. In contrast, FIORE \& JUTTE (2010) found a negative relationship between species richness and sponge biomass when comparing different species of sponges, suggesting that other factors can influence macrofaunal colonization. Although sponges have many functional roles in coastal habitats, the provision of habitat, protection for predation, and settlement surfaces can be of great importance to increase biodiversity in these regions (BELL, 2008).

Epifaunal diversity indicators were more influenced by organic-matter content, suggesting that food resources can be important for the structure of this community. CHRISTIE et al. (2009) found that epifaunal diversity on macrophytes were more closely related to habitat complexity, and that food resources were mainly consumed as particulate organic matter. The availability of organic matter is important for sponge growth and distribution as a food resource (COSTELLO \& MYers, 1987; HadAs et al., 2009), as well as for epi- and endofaunal assemblages (HuANG et al., 2008). Increasing the input of food resources can reduce resource limitation 
for the fauna, enabling the coexistence of more species and therefore increasing diversity (Roy et al., 2000; GIL et al., 2006).

We found that endofaunal assemblages were more stable than epifaunal ones. Endofaunal assemblages were less variable and diversity indicators responded only to variation in sponge volume, suggesting temporal variation only due to space availability. Epifaunal assemblages were more variable, and diversity indicators were related to organicmatter content and, in a lesser degree, to sponge volume, suggesting that these assemblages were more limited by food resources, which vary widely during the year. Therefore, environmental factors influenced epifaunal assemblages more than endofaunal assemblages, and may have important effects on macrofaunal diversity. We conclude that T. ignis supports a diverse assemblage, and that multiple factors influence the diversity and composition of this assemblage, including spatial and food resources. Also, responses to organic-matter variation suggest that these assemblages can be used in biomonitoring studies, but additional sampling contrasting spatial locations is necessary to test this hypothesis.

Acknowledgements. We thank the Fundação de Amparo à Pesquisa do Estado de São Paulo (FAPESP) for the scholarship to L. Pavani (proc. 04/02087-7).

\section{REFERENCES}

ABDo, D. A. 2007. Endofauna differences between two temperate marine sponges (Demospongiae; Haposclerida; Chalinidae) from southwest Australia. Marine Biology 152:845-854.

Amoureux, L. 1966. Étude bionomique et écologique de quelques annélides polyquetes des sables intertidaux de côtes ouest de la France. Archives de Zoologie Expérimentale et Générale 107:12-18.

Ávila, E. \& Ortega-Bastida, A. L. 2014. Influence of habitat and host morphology on macrofaunal assemblages associated with the sponge Halichondria melanadocia in an estuarine system of the southern Gulf of Mexico. Marine Ecology 36(4):1345-1353.

Bell, J. J. 2008. The functional roles of marine sponges. Estuarine, Coastal and Shelf Science 79:341-353.

Bosa, C. R. \& Masunari, S. 2002a. Crustáceos decápodos associados aos bancos de Phragmatopoma caudata (Krõyer) (Polychaeta, Sabellariidae) na Praia de Caiobá, Matinhos, Paraná. Revista Brasileira de Zoologia 19(Supl. 1):117-133.

2002b. Peracáridos associados aos bancos de Phragmatopoma caudata (Krõyer) (Polychaeta, Sabellariidae) na Praia de Caiobá, Matinhos, Paraná. Revista Brasileira de Zoologia 19(Supl. 1):135-147.

Castilla, J. C.; Lagos, N. A. \& Cerda, M. 2004. Marine ecosystem engineering by the alien ascidian Pyura praeputialis on a mid-intertidal rocky shore. Marine Ecology Progress Series 268:119-130.

Christie, H.; Norderhaug, K. M. \& Fredriksen, S. 2009. Macrophytes as habitat for fauna. Marine Ecology Progress Series 396:221-233.

Clarke, K. R. 1993. Nonparametric multivariate analyses of changes in community structure. Australian Journal of Ecology 18:117-143.

Conradi, M.; López-GonzÁlez, P. J.; Cervera, J. L. \& García-Gómez, C. 2000. Seasonality and spatial distribution of peracarids associated with the bryozoan Bugula neritina in Algeciras Bay, Spain. Journal of Crustacean Biology 20:334-349

Costello, M. J. \& Myers, A. A. 1987. Amphipod fauna of the sponges Halichondria panicea and Hymeniacidon perleve in Lough Hyne, Ireland. Marine Ecology Progress Series 41:115-121.

Crain, C. M. \& Bertness, M. D. 2006. Ecosystem engineering across environmental stress gradients: implications for conservation and management. BioScience 56:211-216.
Custódio, M. R. \& Hajdu, E. 2011. Checklist of Porifera from São Paulo State, Brazil. Biota Neotropica 11(1a):1-18. Available at <http://www.biotaneotropica.org.br/v11n1a/en/ abstract?inventory+bn0151101a2011>. Accessed on 30 May 2015.

Duarte, L. F. L. \& Nalesso, R. C. 1996. The sponge Zygomycale parishii (Bowerbank) and its endobiotic fauna. Estuarine, Coastal and Shelf Science 42:139-151.

Fiore, C. L. \& Jutte, P. C. 2010. Characterization of macrofaunal assemblages associated with sponges and tunicates collected off the southeastern United States. Invertebrate Biology 129:105-120.

Garcia, T. M.; Matthews-Cascon, H. \& Franklin-Junior, W. 2009. Millepora alcicornis (Cnidaria: Hydrozoa) as substrate for benthic fauna. Brazilian Journal of Oceanography 57:153-155.

Gil, M.; Armitage, A. R. \& Fourqurean, J. W. 2006. Nutrient impacts on epifaunal density and species composition in a subtropical seagrass bed. Hydrobiologia 569:437-447.

Hadas, E.; ShPigel, M. \& Ilan, M. 2009. Particulate organic matter as a food source for a coral reef sponge. Journal of Experimental Biology 212:3643-3650.

Huang, J. P.; McClintock, J. B.; Amsler, C. D. \& Huang, Y. M. 2008. Mesofauna associated with the marine sponge Amphimedon viridis. Do its physical or chemical attributes provide a prospective refuge from fish predation? Journal of Experimental Marine Biology and Ecology 362:95-100.

JACOBI, C. M. 1987. The invertebrate fauna associated with intertidal beds of the brown mussel Perna perna (L) from Santos, Brazil. Studies on Neotropical Fauna and Environment 22:57-72.

JACOBUCCI, G. B. \& LeITE, F. P. P. 2002. Distribuição vertical e flutuação sazonal da macrofauna vágil associada a Sargassum cymosum C. Agardh, na praia do Lázaro, Ubatuba, São Paulo, Brasil. Revista Brasileira de Zoologia 19(Supl. 1):87-100.

KLitgaARD, A. B. 1995. The fauna associated with outer shelf and upper slope sponges (Porifera, Demospongiae) at the Faroe Islands, northeastern Atlantic. Sarsia 80:1-22.

Koukouras, A.; Russo, A.; Voultsiadou-Koukoura, E.; Arvanitidis, C. \& STEFANIDOU, D. 1996. Macrofauna associated with sponge species of different morphology. Marine Ecology (P. S. N. Z.) 17:569-582.

Koukouras, A.; Voultsiadou-Koukoura, E.; Chintiroglou, H. \& Dounas, C. 1985. A comparison of the macrobenthic animal assemblages associated with seven sponge species. Cahiers de Biologie Marine 26:301-319.

Marin, I. 2007. Pontoniine shrimps inhabiting boring sponges. Zoologische Mededelingen 81:217- 240.

Masunari, S. 1982. Organismos do fital de Amphiroa beauvoisii. I. Autoecologia. Boletim de Zoologia da USP 7:57-148.

Morgado, E. H. \& TANAKA, M. O. 2001. The macrofauna associated with the bryozoan Schizoporella errata (Walters) in southeastern Brazil. Scientia Marina 65:173-181.

Muricy, G. \& Hajdu, E. 2006. Porifera Brasilis: guia de identificação das esponjas mais comuns do Sudeste do Brasil. Rio de Janeiro, Museu Nacional, 104p. (Série Livros, 17).

Nalesso, R. C.; Duarte, L. F. L.; Pierozzi Jr., I. \& Enumo, E. F. 1995. Tube epifauna of the polychaete Phyllochaetopterus socialis Claparède. Estuarine, Coastal and Shelf Science 41:91-100.

Nascimento, E. F. I. \& Rosso, S. 2007. Fauna associada à macroalgas marinhas bentônicas (Rhodophyta e Phaeophyta) da região de São Sebastião, São Paulo. Brazilian Journal of Ecology 11:38-52.

Neves, G. \& Omena, E. 2003. Influence of sponge morphology on the composition of the polychaete associated fauna from Rocas Atoll, northeast Brazil. Coral Reefs 22:123-129.

O’Connor, N. E. \& Crowe, T. P. 2007. Biodiversity among mussels: separating the influence of sizes of mussels from the ages of patches. Journal of the Marine Biological Association of the United Kingdom 87:551-557.

Padua, A.; Lanna, E. \& Klautau, M. 2013. Macrofauna inhabiting the sponge Paraleucilla magna (Porifera: Calcarea) in Rio de Janeiro, Brazil. Journal of the Marine Biological Association of the United Kingdom 93:889-898.

Pawlik, J. R.; McMurray, S. E. \& Henkel, T. P. 2007.Abiotic factors control sponge ecology in Florida mangroves. Marine Ecology Progress Series 339:93-98. 
Peattie, M. E. \& Hoare, R. 1981. The sponge Halichondria panicea (Pallas) and its associated fauna. Estuarine, Coastal and Shelf Science 13:621-635.

Ribeiro, S. M.; Omena, E. P. \& Muricy, G. 2003. Macrofauna associated to Mycale microsigmatosa (Porifera, Demospongiae) in Rio de Janeiro State, SE Brazil. Estuarine, Coastal and Shelf Science 57:951-959.

Roy, K.; Jablonski, D. \& Valentine, J. W. 2000. Dissecting latitudinal diversity gradients: functional groups and clades of marine bivalves. Proceedings of the Royal Society of London, Series B: Biological Sciences 267:293-299.

SEBENS, K. P. 1991. Habitat structure and community dynamics in marine benthic systems. In: Bell, S. S.; McCoy, E. D. \& Mushinsky, H. R. eds. Habitat structure - the physical arrangement of objects in space. London, Chapman and Hall, p. 211-234.

Skilleter, G. A.; Russell, D. B.; Degnan, B. M. \& Garson, M. J. 2005. Living in a potentially toxic environment: comparisons of endofauna in two congeneric sponges from the Great Barrier Reef. Marine Ecology Progress Series 304:67-75.

TANAKA, M. O. \& Leite, F. P. P. 2003. Spatial scaling in the distribution of macrofauna associated with Sargassum stenophyllum (Mertens) Martius: analyses of faunal groups, gammarid life habits, and assemblage structure. Journal of Experimental Marine Biology and Ecology 293:1-22.
TARARAM, A. S. \& WAKabara, Y. 1981. The mobile fauna - especially Gammaridea - of Sargassum cymosum. Marine Ecology Progress Series 5:157-163.

Villamizar, E. \& LAUGHLIN, R. A. 1991. Fauna associated with the sponges Aplysina archeri and Aplysina lacunosa in a coral reef of the Archipiélago de Los Roques, National Park, Venezuela. In: ReITNER, J. \& Keupp, H. eds. Fossil and recent sponges. Berlin, Springer, p. 522-542.

Voultsiadou, E.; Pyrounaki, M. M. \& Chintiroglou, C. 2007. The habitat engineering tunicate Microcosmus sabatieri Roule, 1885 and its associated peracarid epifauna. Estuarine, Coastal and Shelf Science 74:197-204.

Voultisiadou-Koukoura, H. E.; Koukouras, A. \& Eleftheriou, A. 1987. Macrofauna associated with the sponge Verongia aerophoba in the North Aegean Sea. Estuarine, Coastal and Shelf Science 24:265-278.

Westinga, E. \& Hoetjes, P. C. 1981. The intrasponge fauna of Spheciospongia vesparia (Porifera, Demospongiae) at Curaçao and Bonaire. Marine Biology 62:139-150. 